\title{
Data Validation Test Document
}

National Cancer Institute

\section{Source}

National Cancer Institute. Data Validation Test Document. NCI Thesaurus. Code C115686.

Records pertaining to the completion of a data validation test. 